\title{
Analysis of Masseter Muscle Tension through Electromyography among Residents of the City of Buenos Aires - Argentina
}

\author{
Marcus Vinícius de Mello Pinto ${ }^{1 *}$, Francisco José Pereira $\mathbf{J r}^{2}$, Guilhermo Mario Scaglione ${ }^{3}$, \\ Sebastião David Santos-Filho ${ }^{4}$, Cristiane Martins da Silva ${ }^{5}$, Marco Antônio Guimarães da \\ Silva $^{6}$, Lamara Laguardia Valente Rocha ${ }^{7}$ and Reggiani Vilela Gonçalves ${ }^{8}$ \\ ${ }^{1}$ Fac Redentor - Endereço: Rod BR 35,n.25, Cidade Nova-Itaperuna, Brasil, 28300-000. ${ }^{2}$ Universidade do Grande \\ Rio, Programa de Pós-Graduação em Odontologia; Rua Prof. José De Souza Herdy, 1160, Jd. 25 De Agosto, \\ Duque De Caxias-RJ, Brasil, 25071-202. ${ }^{3}$ Universidade De Buenos Aires, Faculdade de Medicina, Departamento \\ de Kinesiologia e Fisiatria, Paraguay. 2155. Capital Federal (Cp:Cl121abg), Argentina. ${ }^{4}$ Universidade do Rio de \\ Janeiro, Departamento de Biofísica e Biometria, Instituto de Biologia Roberto Alcantara Gomes,Av.28 de \\ Setembro,87,Rio De Janeiro-RJ, Brasil, 20551030. ${ }^{5}$ Fac Redentor - Endereço: Rod BR 35,n.25, Cidade Nova- \\ Itaperuna, Brasil, 28300-000 ${ }^{6}$ Universidade Federal Rural do Rio De Janeiro, Departamento de Educação Física e \\ Desportos. Antiga estrada Rio São Paulo Km,47, 23851-910 - Seropédica-RJ, Brasil. ${ }^{7}$ Centro Universitário de \\ Caratinga, Campus II. Laboratório de Dor Orofacial e Eletromiografia Clinica. Endereço: Rua Niterói, S/N. Bairro \\ Nossa Senhora Das Graças, Caratinga-MG, Brasil, Cep 35300-000. ${ }^{8}$ Universidade Federal de Pelotas, Rua Gomes \\ Carneiro, $1 \cdot$ Centro $\cdot$ CEP 96010-610 $\cdot$ Pelotas, RS,Brazil,96001-970
}

\begin{abstract}
This study aimed at collecting data of masseter myofascial tension, related to the joint hyperactivity by electromyography activity of masseter muscle at rest, isotonic and isometric chewing. 08 patients living in the city of Buenos Aires, Argentina, volunteers, aged between 22 and 62 years, both sexes were evaluated. The electromyography data collection at rest had reported that 50\% showed differences in masseter muscle tension increased in the left for the right masseter; in isometric contraction, 50\% had a difference in masseter tension right; in isotonic contraction $62.5 \%$ there was a difference in increased tension in the left masseter. Anthropometry of the face was suggested, where $25 \%$ showed significant variance of $01 \mathrm{~cm}$ of discrepancy on the right, in relation to the left. It is possible in the future, an early diagnosis and treatment, thus avoiding a source of pain, speech disorders and problems in the mastication system. For this we need to establish a direct follow-up control of at least one year after the treatment strategy.
\end{abstract}

Key words: Muscle tension, masseter, Electromyography

\section{INTRODUCTION}

Currently, professionals from various areas of expertise had developed an interest in knowing the temporomandibular joint (TMJ), also known as craniomandibular joint (CMJ), the most complex of the human body for its anatomy, its handling capacity, as well as being two joints in a single

*Author for correspondence: orofacial_1@hotmail.com 
bone (Okeson 1998; Okeson 1992; Zanini 1999; Duringan et al. 2009).

The articulation of the jaw to the temporal bone belongs to the type of synovial joint, TMJ. It is a combination of ginglymus and flat hollow, formed by the mandibular condyle, which articulates the mandibular fossa of the temporal bone. Among (Between) them there is the hard bone joint that allows the complex movements of the joint, so they do not articulate directly. The synovial joints are generally very mobile and have elements of capsules, cavity, articular surfaces and ligaments (Balbinote 2003; Henry Gray 1999; O'rahillt, 1988; Öcal et al. 2009).

The terminology temporomandibular disorder (TMD) is adopted by the American Dental Association to cite this disorder, when there is pain in the preauricular region, in the masticatory muscles or TMJ, sounds in this joint during jaw function and limitations of jaw extension movements (Bassanta et al. 1997; Machado 1998).

The masseter corresponds to one of the muscles of mastication. It is a quad, thick muscle, which is located on the side of the mandible and is divided into portions partly superficial, middle and deep. The masseter muscle is supplied by the trigeminal nerve, mandibular division. It is a powerful lifter jaw and is considered the main muscle for that function. The superficial fibers help to pull the jaw forward during the movement of protraction (Henry Gray 1999; O'rahillt, 1988; Palastanga et al. 2000).

The principal characteristic of myofascial pain includes muscle weakness and pain point, called trigger points, local and referred pain. However, myofascial pain, particularly in the head and neck, has numerous findings and common associations with joint disorders and other painful disorders that can lead to misdiagnosis (Fricton 1999).

In Buenos Aires, Argentina, the incidence of pain on masseter muscle tension is $44.5 \%$, and the female community is the most affected, according to the Pain Clinic of the Hospital de Clinicas, Universidad de Buenos Aires - AR. The female has joint laxity that does not stabilize the TMJ. Myofascial tension is often seen as a common cause of persistent pain (Fricton 1999; Henry and Weinman 1951; Lam et al. 2001; Okeson 1992; Pow et al. 2001).

According to the literature review, electromyographic studies have shown that the temporomandibular disorders (TMD's), produce uncoordinated activity of masticatory muscles (Fricton 1999; Turcio 2002).

The procedure of electromyography (EMG) compares the electrical activity of skeletal muscle fibers at rest and during voluntary muscle activation. As any clinical procedure, a variety of conditions or situations may limit or prevent the use of electrophysiological assessment procedures. The examiner should be careful, beyond other conditions, about the application in patients with external swelling, dermatitis, non-cooperative attitude, recent myocardial infarction, immune suppression, pacemaker, and hypersensitivity to stimulation, open wounds and burns (Robinson and Snyder-Mackler 2002).

This study aimed at collecting data of myofascial tension in masseter muscle related to joint hyperactivity, by electromyographic activity of masseter muscle at rest, isotonic and isometric chewing.

The speech is an instrument of a daily use, among other educational and pedagogical contexts, with an intense muscular activity that can generate a higher level of stress, thus causing hyperactivity TMJ and muscle tension. The end result can be irritability, sleep disturbances, making a cycle of negative feedback, resulting in a decrease of the human functional activities. Almost (Quite) often this relationship with the disorder goes unnoticed in the overview of the subject, however, bringing great future losses in their lives (Zanini 1999).

\section{MATERIALS AND METHODS}

To carry out this research, an analytical study was developed. 08 (eight) patients were evaluated at the clinics of the University of Buenos Aires, Pain Clinic, volunteers, aged between 22 and 62 years by signing the consent form complying the resolution 196/96 of the National Council of Health and the Institutional Ethics Committee.

In this study, patients were selected in an asymptomatic group, previously evaluated in this service, to determine the criteria for inclusion and exclusion.

The inclusion criteria that determined this methodology were the availability of time of the patients; the presence of spontaneous exacerbated masseter tension; and the presence of spontaneous pain and/or palpation in clinical orofacial evaluation. 
They were excluded patients who did not meet the criteria for inclusion; who were not registered in the outpatient pain; who had presence of external edema, dermatitis, immunosuppressant, pacemaker, hypersensitivity to stimulation, open wounds and burns; who were not cooperative; who had had myocardial infarction recently; who had psychological disorders; and who had cervical disorders.

The electromyographic examination was performed during the morning. The temperature of the laboratory for the experiment was between $18^{\circ} \mathrm{C}$ to $26^{\circ} \mathrm{C}$. The patients were seated and their face cleaned with $70 \%$ alcohol. Two self-adhesive electrodes, from a surface electromyography, were added in the masseter, and it was made a test to check if all the electrodes were properly fixed. The patients were requested to relax the muscles and, after notice, to implement the maximum voluntary contraction, and its continuity throughout the test (from 20 to 35 seconds). After that, it was developed a sequence of 10 (ten) tapas range from 02 to 05 seconds, without a break to rest. The signal acquired was recorded with the use of SAD 32 , to be processed later.

It was elected electromyography sensors, load cell and board self-adhesive EMG System of Brazil LTDA. The equipment consists of an electromyography board A / D internal resolution with 16 Bites and sampling rate above $30 \mathrm{kHz}$ in each channel. The maximum input voltage electricity in electromyography is approximately 5 volts, the conversion speed myoelectric in the order of $25 \mathrm{~ms}$.
The curve of static calibration of the sensor load cell is of type $\mathrm{Y}=11.74+366.24 . \mathrm{X}$, this mathematical numeral tells you how to load the vector that the masseter may receive in clinical examination.

The computer used was a notebook Pentium 4, Metron of $01 \mathrm{Ghz}$, with an HP 610-C. The computer system used was the EMG SYSTEM Brazil. This instrument is called Aq-data electromyography. This project did not aim at significant risk to human volunteers. The difficulty for the implementation of the project was the availability of time of volunteers.

\section{RESULTS}

The data collected in this study were analyzed in interferential, with the application of descriptive analysis, and estimate interpretation with statistical significance, because the data were not consistent with the application of parametric test. This fact can be justified, given the state of the contra lateral muscle tension and biomechanics of the temporomandibular joint of the sample.

Statistically, the results appear to be positive, as below, showing the important changes that should be identified.

Figure 1 shows facial anthropometry of 08 voluntary evaluated patients. It was noticed that $25 \%$ of the volunteers showed significant variance of $01 \mathrm{~cm}$ (one centimeter) of discrepancy on the right, in the left.

\section{FACIAL ANTROMOMETRY}

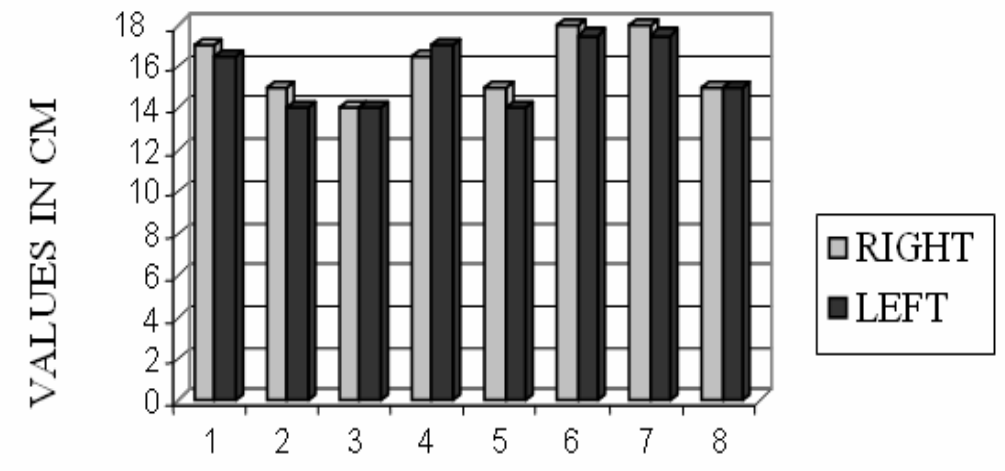

\section{PATIENTS}

Figure 1 - Graphical representation of facial anthropometry, comparing the right side with the left, after electromyographic examination. 
Figure 2 shows the electromyographic examination of the masseter muscle bilaterally at rest, in 08 voluntary evaluated patients. A significant variance was seen. $50 \%$ of patients showed greater tension difference on the left, $25 \%$ of patients showed greater tension difference on the right and $25 \%$, without difference tension.

Figure 3 shows the electromyographic examination of the masseter muscle bilaterally in isometric contraction of 08 evaluated patients. A significant variance was seen. $50 \%$ of patients had increased tension difference on the right, left $25 \%$ and $25 \%$ without any significant tension.
Figure 4 shows the electromyographic examination of the masseter muscle bilaterally in isotonia, of 08 evaluated patients. A significant variance was also noticed. It had been used, for better reliability of the test, load cells of masticatory strain gauge, and it was found that the masticatory muscle strength on the left is more present in strength and willingness of the masseter muscle fibers, in the order (?) of $62.5 \%$ of patients had greater difference tension on the left, right $25 \%$ and $12.5 \%$ without any significant tension.

ELECTROMYOGRAPICH

EXAMINATION AT REST

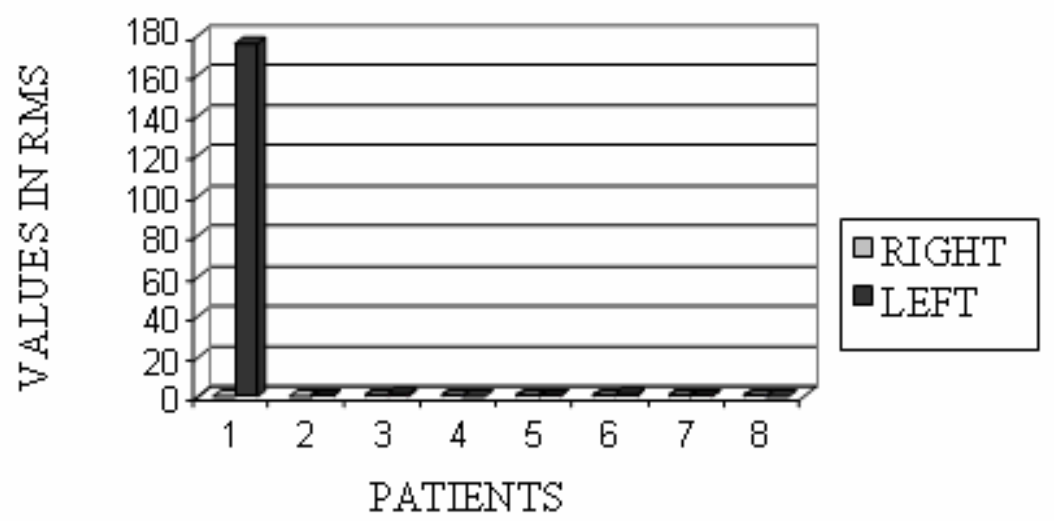

Figure 2 - Graphical representation of electromyographic examination at rest, comparing the masseter muscles right and left.

\section{ELECTROMYOGRAPHIC EXAMINATION IN ISOMETRY}
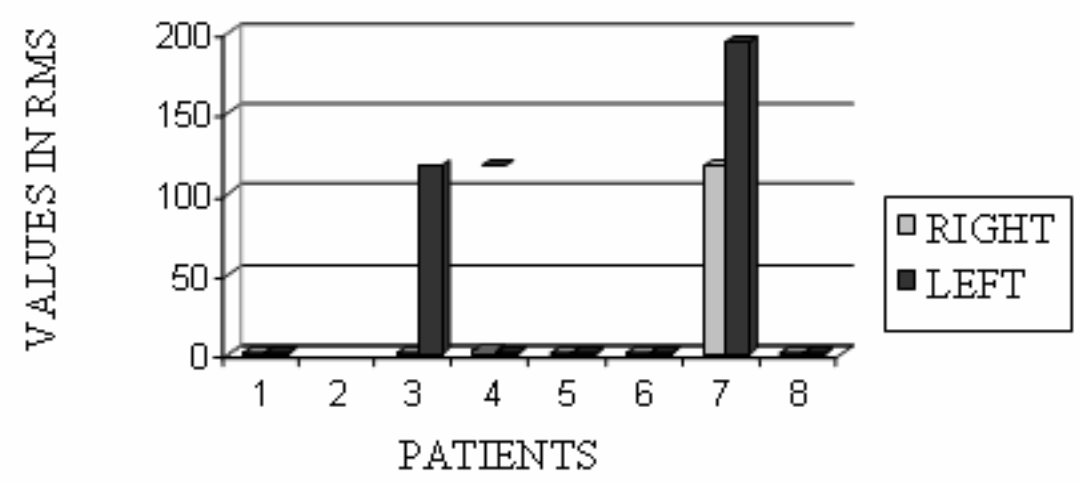

Figure 3 - Graphical representation of electromyographic examination in isometry, comparing the masseter right and left. 


\section{ELECTROMYOGRAPHIC EXAMINATION IN ISOTONIA}

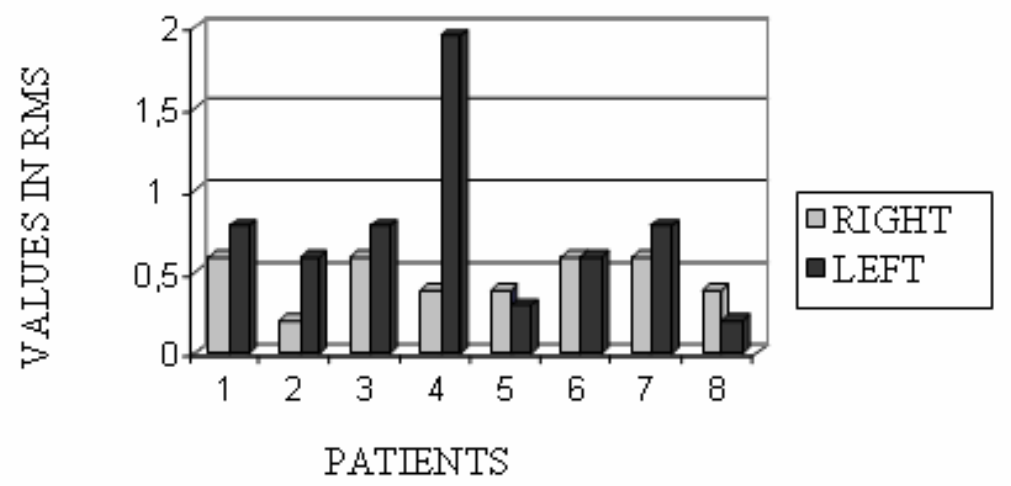

Figure 4 - Graphical representation of electromyographic examination in isotonic contraction comparing the masseter right and left.

\section{DISCUSSION}

The results of this clinical study, although satisfactory in terms of the three levels of masticatory muscle contraction, have their importance as clinical development for future work, and increasingly encouragement for the practice of research.

These findings contrast with the results of Turcio's research (2002), which had shown a co-dominance contraction in $90 \%$ of the sample on the right side. On the other hand, the results of this study showed co-dominance and functional disorder contraction left, $62,5 \%$. This clinical episode presented over the levels of work activity of the sample population involved in this work.

According to the results of this research, it was suggested that the anthropometry of the face, with verification of speed curve, and observed a ratio of $25 \%$ of volunteers showing a discrepancy of 01 (one) inch of the TMJ right for left TMJ (Molina 1989).

The data at rest within the surface electromyographic evaluation were the standard of significance, because $50 \%$ of the sample had higher blood pressure differences in masseter muscle left in the law, in this case the literature reinforces biomechanical changes in the TMJ, since this work in alternating curves speed giving change in the mechanics of the TMJ joint (Pinto et al. 2003; Bakke et al. 1989).

The values obtained electromyographically provided isometric masseter showed a variable of $50 \%$ from the sample studied, considering that the right masseter muscle presented higher viability contraction force and tension, the authors suggest that in isometric contraction the mechanical joint undergoes a physiological change, as the concentration of power masseter changes the axis for setting the five aponeurose of the masseter muscle, so overloading one side compared to the other, the temporomandibular joint (Bakke et al. 1993).

In conducting electromyographic to verify isotonic contraction chewing in this study, we observed that $62.5 \%$ of the population sample studied had had significant tension in the left masseter muscle and $25 \%$ in the right masseter muscle and $12.5 \%$ had been in bilateral equivalence masseter muscles. The movement involved during the chewing isotonic cycle, in general, varies in degree, strength and occlusal discrepancy. Thus, the biomechanical state of the TMJ joint will be responsible for changes in the myoelectric signal seen in the collection of this electromyographic research (Okeson 1998).

\section{CONCLUSION}

According to statistical analysis, we concluded that there was a change in the electromyographic signal of the left masseter muscle, in the law, and in rest $50 \%$ of the sample difference greater tension in the left masseter and isotonic contration with $62.5 \%$ of patients a larger difference tension on the left, in contrast to the electromyographic signal in isometric showed that $50 \%$ of the sample 
population with different tension on the right. Thus, we observed that in this case the literature reinforces biomechanical changes in TMJ, since this work in the alternation of curves speed giving change in the mechanics of the TMJ joint.

The speech, as an instrument of daily and professional use, can be an aggravating factor that needs a diagnosis and early treatment to avoid in the future, a source of pain, speech disorders and mastication system. Justified conduct a detailed study with an $\mathrm{N}$ most significant and randomized control studies so that, can be observed the level of facial masseter muscle dysfunction, so that in future, act at the level of primary health care of such involvement, aimed at prevention, promotion and recovery of functional structures injured skull mandibular joint.

\section{REFERENCES}

Balbinot, A. (2003), Sistema experimental, assistido por computador desenvolvido para medições do período de silêncio de pessoas com problemas na articulação têmporo-mandibular. In: <http://www.abopa.org.br/ Materiacientif.htm $>$. Accessed in $5^{\text {th }}$ jun

Bakke, M.; Micheler, L.; Hank. \& Möller, E. (1989), Clinical significance of isometric bite force versus electrical activity in temporal and masseter muscles. Scand J Dent Res., 98, 539-51

Bakke, M.; Stolze, K.; Tuxen, A. (1993), Variables related to masseter muscle function: a maximum $\mathrm{R}^{2}$ improvement analysis. Scand J Dent Res, , 1001, 15965

Bassanta, A.D.; Sproesser, J.G.; Paiva, G. (1997), Estimulação Elétrica Transcutânea ("TENS"): sua aplicação nas disfunções têmporo-mandibulares. Ver. Odontol Univ., 11(2), 109-116

Durigan, João Luiz Quagliotti et al. (2009), Metabolic and morphometric alterations inherent to neuromuscular electric stimulation in the antagonist muscle submitted to ankle joint immobilization. Braz. Arch. Biol. Technol., 1, 85-91

Fricton, J.R. (1999), Masticatory Myofascial Pain. Bull Group Rech Sci Stomatol Odontol. 1, 14-25

Henry Gray, F.R.S. (1999), Gray Anatomia. $29^{\mathrm{a}}$ ed. Guanabara, Rio de Janeiro-RJ, pp. 242-243.

Henry, J.L.; Weinman, J.P. (1951), The patterns of the resorption and repair of human cementum. J. Amer. Dent Ass., 42, 270.

Lam, D.K.; Lawrence, H.P.; Tenenbaum, H.C. (2001), Aural Symptoms in Temporomandibular Disorder Patients Attending a Craniofacial Pain Unit. 15, 2.
Machado, S.G. (1998), Disfunções têmporomandibulares: Fatores etiológicos e consequiência da musculatura mastigatória.. Monografy, especialization in oral motricity - Centro de especialização em fonoaudiologia clínica motricidade oral, São Paulo, Brasil

Molina, O.F. (1989), Fisiopatologia Crânio Mandibular. Editora Pancast, pp. 372-373

Öcal, Isil and Günay, Ismail The effects of chronic AC magnetic field on contraction and relaxation of isolated thoracic aorta rings of healthy and diabetic rats. (2009). Braz. Arch. Biol. Technol., 47, 733-738

Okeson, J.P. (1998), Dor Orofacial: guia de avaliação, diagnóstico e tratamento. Tradução de Kátia Dmytrazenko Franco. São Paulo, Quintessence Editora Ltda, pp. 287

Okeson, J.P. (1992), Fundamentos de oclusão $e$ desordens têmporo-mandibulares. Tradução de Milton Edson Miranda. Porto Alegre, Artes Médicas, pp. 449.

O`rahillt, G. (1988), Anatomia: Estudo Regional do Corpo Humano. $4^{\mathrm{a}}$ ed. Guanabara, Rio de Janeiro, pp.652-653

Palastanga, N.; Field, D.; Soanes, R. (2000), Anatomia e Movimento Humano - Estrutura e Função .Manole, São Paulo.

Pinto, M.V.M. et al. (2003), X Congresso Brasileiro de Biomecânica. Título: Estudo da Eletromiografia de superfície em 40 pacientes portadores de tendinite do músculo masseter. Editora: CAPES, CNPQ e FAPEMIG, p.376.

Pow, E.H.N.; Leung, K.C.M.; Macmillan, A.S. (2001), Prevalence of Symptoms Associated with Temporomandibular Disorders in Hong Kong Chinese. Journal of Orofacial Pain. 15, 3, pp. 228234.

Robinson, A.J.; Snyder-Mackler, L. (2002), Eletrofisiologia Clínica: Eletroterapia e teste eletrofisiológico. $2^{\mathrm{a}}$ ed. Artmed, Porto Alegre, pp.353

Turcio, K.H.L. et al. (2002), Avaliação eletromiográfica e eletrovibratográfica antes e após o tratamento da desordem têmporo-mandibular. Monografia, pós-graduação área de concentração em Prótese Dentária, Faculdade de Odontologia de Araçatuba - UNESP. PGRO-Pós-Grad Rev. Odontol, $.5,2$, maio/ago.

Zanini, C.F.C. (1999), Os hábitos parafuncionais na disfunção da articulação têmporo-mandibular. Porto Alegre, 1999. 62 (f.). Monografy, especialization in oral motricity - Centro de especialização em fonoaudiologia clínica motricidade oral, Porto Alegre, RS. 